\title{
Teacher as a Designer of Project-Based Learning Practice*
}

\author{
JIANG Bo, LIU Li \\ Dalian University of Technology, Dalian, China
}

\begin{abstract}
To apply designing within practice of PBL (Project-Based Learning) approach and to help teachers develop identities as designers, this article introduces the designing principles for teachers in project-based learning, including to be tailored to the development of new technology, to cover more than two disciplines, to pose a real problem for students, to foster students' creativity, to ask students to present their job responsibility, and to promote autonomous learning.
\end{abstract}

Keywords: PBL, teacher's role, instructional design

\section{Introduction}

With more and more various ways of reform of instruction emerging, designing is becoming a central piece of teacher practice. Teachers are increasingly adopting the role of designer as part of their practice (Laurillard, 2012). It is considered as an important area of focus for professional development, which highlights that design represents an important capacity in the set of skills required for teachers (McKenney, Kali, Markauskaite, \& Voogt, 2015). By casting teachers as designers of learning experiences and situating design as a component of teachers' professional work (Handelzalts, 2009), there is an opportunity for teachers to develop as reflective practitioners (Schön, 1987). Our present research is to apply designing within practice of PBL approach and illustrate how to be an efficient designer.

\section{Designer-the Role of a Teacher}

Teachers are designers of learning experiences to emphasize teacher involvement in designing from pre-instructional designing of lessons, activities, units, and learning environments to their design work that continues into the classroom (Schön, 1983, 1987, 1992; Minstrell, Anderson, \& Li, 2011; Cober, Tan, Slotta, So, \& Könings, 2015).

According to Luehmann (2002), support for adapting curricula should include identifying local needs, critiquing the innovation in light of these needs; visualizing possible scenarios of implementation; and finally, making plans or decisions regarding the implementation; this description of adaptation resonates professional design practice in fields such as architecture and engineering.

\footnotetext{
* Acknowledgements: This paper was sponsored by the Funds of Project: Learning motivation regulation strategy in ESP project, and also funded by the Graduate Project for Teaching: Application multimodal English presentationvideos in graduates courses in mobile learning environment.

JIANG Bo, lecturer, master, Software School, Dalian university of technology.

LIU Li, lecturer, master, Software School, Dalian university of technology.
} 


\section{Project-Based Learning}

The primary purposes of project-based learning are to enable students to use what they have learned and to integrate the theory and practices learned by students. They can then realize their imagination and creativity, converting their knowledge into abilities to cope with the challenges of life and work (Hsiao, 1997). With the constructivist theories of Jean Piaget, Blumenfeld, Soloway, Marx, Krajcik, Guzdial, and Palincsar (1991) elaborate on the processes of PBL:

Project-based learning is a comprehensive perspective focused on teaching by engaging students in investigation. Within this framework, students pursue solutions to nontrivial problems by asking and refining questions, debating ideas, making predictions, designing plans and/or experiments, collecting and analyzing data, drawing conclusions, communicating their ideas and findings to others, asking new questions, and creating artifacts. (pp. 369-398)

Project-based learning advocates for the creation of a learning context in which students can actively participate and discuss, and it suggests the use of these contexts to inspire students' learning interests (Polman, 1998), using driving questions to elicit various learning activities. The problems posed by the projects are challenging, and in the learning process, students must propose and define questions, collect data, cooperate in learning, and create concrete achievements, all of which inspire their creative thinking abilities. In addition, using diverse instructional strategies has been proven to cultivate student creativity (Michaela, 2001).

\section{Instructional Designing Principles in Project-Based Learning}

We have many factors to bear in mind when we design the project for students. The factors include: meeting demand of new technology, posing a real problem for students, covering more than two disciplines when doing the project, fostering students' creativity, asking students to present their job responsibility, and improving autonomous learning.

\section{Design to Be Tailored to the Development of New Technology}

With the development of digital technology, instructional strategies and tools have changed. Instructional design must evolve with them. Teachers should design a lesson plan to align to an instructional reform. Designing activities includes making adaptations to existing curricula during or prior to instruction and designing new learning experiences. Not only do we want teachers to have the capacity to make adaptations to curricula that bring new technology-enhanced learning into their classrooms in ways that fit, we also want them to have the capacity to design new technology-enhanced learning experiences (Vanessa, Richard, Ornit, \&Yael, 2015). We need to give students opportunities to fully apply new technology to their project. We design a task in which students need to get online and search for information. They also need to generalize and analyze what they have gained from the internet and share views with peers on it.

\section{Design to Cover More Than Two Disciplines}

Taking the major field of students into consideration, we design the project to expand both major knowledge and foreign language skills. For instance, for software majors, we provide them with a project of making English learning software, which combines two skills: how to make software and how to give a presentation in English on the whole process.

On the one hand, all of the students have 12 years of learning English (In China, students learn English from grade one in primary school). They have rich experience of learning English and know about the demand of it when making software. On the other hand, students are wholly involved in five stages of process of 
making software: need requirement analysis, designing interface, coding, software testing, and software maintenance. Their job responsibility includes designing questionnaires and collecting answers from customers about the needs for software; designing interface based on customers need; converting a piece of information into another form or representation; executing a program or application with the intent of finding software bugs and debugging; stable operation, improvement of the system, regular optimization of existing software, and handling application software failures. The project practices their research capabilities, designing and art skill, coding skill, testing skill, and problem-solving skill.

\section{Design to Pose a Real Problem for Students}

In PBL, students face a challenging task, and their designs, problem-solving, decision-making, and research allow them to autonomously conduct work related to the topic during a period of time, completing a real product (Thomas, 2000). The basis of PBL lies in the authenticity or real-life application of the learning. The real problem stimulates students' interest and motivation, especially when students have the expectation that their real product will be used by themselves and their peers. For software majors, the real-world problem is to make software. When students have hands-on experience, they are much clearer about the process of making software and the different task in each stage. They practice distributing a certain amount time to a specific smaller assignment so that they can fulfill the whole task. They are also aware of the importance and realization of connecting functions from one stage to another.

\section{Design to Foster Students' Creativity}

If creative thinking capabilities could be incorporated into courses, students could form and develop creative ideas and increase their imagination allowing them to see problems from other perspectives and to cultivate problem-solving ability (Maisuria, 2005). The education and promotion of creativity in university technological education is a significant issue. The project of making software gives students great chances to experience and sense creativity, from need analysis to interface design; students should create questionnaires by themselves and make design by themselves. This tests their ability of actualization of the innovation and inspiration with their own understanding for the project.

\section{Design to Ask Students to Present Their Job Responsibility}

Project-based learning has been associated with the "situated learning" perspective of Greeno (2006) and students working as a team are given a "driving question" to respond to or answer, then directed to create an artifact (or artifacts) to present their gained knowledge. Artifacts may include a variety of media such as writings, art, drawings, three-dimensional representations, videos, photography, or technology-based presentations.

Artifact in our project is to give a presentation on job responsibility. Students have the opportunity to reflect on the acquired knowledge during the project, including how they identify knowledge deficiencies for solving the problem, how they generate ideas for problem solving, and how they look for new knowledge related to the domain as well as the following try to generate facts about the new knowledge. The job responsibility in each stage varies. Respectively, students conduct need requirement analysis; design interface, code, test; and maintain software.

\section{Design to Promote Autonomous Learning}

Boaler (2002) noted that, in project-based learning, students were more responsible for autonomous 
learning and learnt more than from other instructional models (Boaler, 2002). The teacher acts as a facilitator in the learning process, instead of just transmitting knowledge (Fontes, Mendes Neto, Pontes, \& Campos, 2011). $\mathrm{He} / \mathrm{she}$ guides students to apply their acquired knowledge in new situations. The learning is student centric and self-directed. Students, organized in small collaborative groups, are motivated to discover, through investigation and research, useful solutions (Laysa, Francisco, \& Alexandre, 2011).

When students take responsibility, or ownership, for their learning, their self-esteem soars. It also helps to create better work habits and attitudes toward learning. Although students do work in groups, they also become more independent because they are receiving little instruction from the teacher. The students learn more than just finding answers and PBL allows them to expand their minds and think beyond what they normally would.

\section{Conclusion}

PBL engages student voice by encouraging students to take full responsibility for their learning. When applied, PBL offers some benefits, among which these stand out (Hmelo-Silver, 2004):

Develops critical thinking and creativity on the student;

Improves his ability to solve problems;

Improves motivation;

Helps students apply the knowledge they acquired to new situations.

Students become constructivists by working together to accomplish specific goals. Instead of being passive ones while teacher transmitting the information, students take on an active role. They constantly make choices on how to obtain, display, or manipulate information. Technology tools help them to communicate and every student has the opportunity to get involved either individually or as a group. The project-based learning is a student-centered pedagogy, and teacher acts as a designer for the project conducted by students, with a deep understanding of PBL and with an overall capability improvement as the goal in mind.

\section{References}

Boaler, J. (2002). Experiencing school mathematics: Traditional and reform approaches to teaching and their impact on student learning. Mahwah: Lawrence Erlbaum Associates Inc..

Cober, R., Tan, E., Slotta, J., So, H. J., \& Könings, K. D. (2015). Teachers as participatory designers: Two case studies with technology-enhanced learning environments. Instructional Science, 43, 203-228. doi:10.1007/s11251-014-9339-0

Coutinho, C. M. P., \& Junior, J. B. (2007). Collaborative learning using Wiki: A pilot study with master students in educational technology. Proceedings of World Conference on Educational Media and Technology, Vancouver, Canada.

Fontes, L. M. O., Mendes Neto, F. M., Pontes, A. A. A., \& Campos, G. A. L. (2011). An agent-based architecture for supporting the workgroups creation and the detection of out-of-context conversation on problem-based learning in virtual learning environments. Proceedings of the 2011 ACM Symposium on Applied Computing (SAC) (pp. 1175-1180), TaiChung, Taiwan.

Greeno, J. G. (2006). Learning in activity. In R. K. Sawyer (Ed.), The Cambridge handbook of the learning sciences (pp. 79-96). New York: Cambridge University Press.

Handelzalts, A. (2009). Collaborative curriculum development in teacher design teams (Doctoral thesis, University of Twente, Enschede).

Hmelo-Silver, C. E. (2004). Problem-based learning: What and how do students learn? Educational Psychology Review, 16, 235-266. doi:10.1023/B:EDPR.0000034022.16470.f3

Hsiao, H. C. (1997). The improvement of creativity and productivity of technical workers through partnership between university and industry. Paper presented at the International Conference on Creativity Development in Technical Education and Training, Taipei.

Laurillard, D. (2012). Teaching as a design science: Building pedagogical patterns for learning and technology. London: Routledge, Taylor \& Francis Group. 
Laysa, M. O. F., Francisco, M. M. N., \& Alexandre, A. A. P. (2011). A multiagent system to support problem-based learning. Creative Education, 2(5), 452-457.

Luehmann, A. (2002). Powerful hidden forces affecting teachers' appraisal and adoption of innovative technology-rich curricular supports for secondary water quality learning. Paper presented to the American Educational Research Association, New Orleans, LA. Retrieved April 1, 2007 from http://mail.rochester.edu/ lumn/pink/index.htm

Maisuria, A. (2005). The turbulent times of creativity in the National Curriculum. Policy Futures in Education, 3, $141-152$. doi:10.2304/pfie.2005.3.2.3

McKenney, S., Kali, Y., Markauskaite, L., \& Voogt, J. (2015). Teacher design knowledge for technology enhanced learning: An ecological framework for investigating assets and needs. Instructional Science, 43(2), 181-202. doi:10.1007/s11251-014-9337-2

Michaela, D. (2001). Fostering creativity in business education: Developing creative classroom environments to provide students with critical workplace competencies. Journal of Education for Business, 77, 28-33. doi:10.1080/08832320109599667

Minstrell, J., Anderson, R., \& Li, M. (2011). Building on learner thinking: A framework for assessment in instruction. Paper presented for the Committee on Highly Successful STEM Schools or Programs for K-12 STEM Education, Vancouver.

Polman, J. L. (1998). Activity structures for project-based teaching and learning: Design and adaptation of cultural tools. Annual Meeting of AERA, San Diego.

Blumenfeld, P. C., Soloway, E., Marx, R. W., Krajcik, J. S., Guzdial, M., \& Palincsar, A. (1991). Motivating project-based learning: sustaining the doing, supporting the learning. Educational Psychologist, 26(3\&4), 369-398.

Schön, D. A. (1983). The reflective practitioner: How professionals think in action. New York: Basic Books.

Schön, D. A. (1987). Educating the reflective practitioner. San Francisco: Jossey-Bass.

Schön, D. A. (1992). Designing as reflective conversation with the materials of a design situation. Research in Engineering Design, 3(3), 131-147.

Thomas, J. W. (2000). A review of research on project-based learning. San Rafael, CA: Autodesk Foundation.

Vanessa, S., Richard, R., Ornit, S., \& Yael, K. (2015). A finger print pattern of supports for teachers' designing of technology-enhanced learning. Instructional Science, 43, 283-307. 